\title{
MIGRATION FACTORS RELATED TO EMIGRATION INTENTIONS AMONG UNIVERSITY STUDENTS IN SLOVAKIA
}

\author{
Bohuš Hajduch $^{1}$, Olga Orosová $^{\mathbf{2}}, \boldsymbol{\&}$ Marcela Štefaňáková ${ }^{1}$ \\ ${ }^{1}$ Department of Psychology, Faculty of Arts, P.J. Safarik University in Košice (Slovakia) \\ ${ }^{2}$ Department of Educational Psychology and Psychology of Health, Faculty of Arts, P.J. Safarik \\ University in Košice (Slovakia)
}

\begin{abstract}
Background: In Slovakia, there has been an increase in the number of students who aim to move abroad. We hypothesized that experience with living abroad might increase the likelihood of emigration intentions because people (in this study, university students) with migration experience might feel more confident after carrying out and experiencing their emigration intentions.

Objectives: The main objective of this study was to explore whether factors such as emigration self-efficacy (ESE), evaluation of migration experience (EME) and the frequency of migration experience (FME) are related to the emigration intentions (EI) of young people (under 30 years old) in Slovakia. The moderation effect of gender in the relationship between the independent variables and dependent variable (EI) was also tested.

Methods: The sample consisted of 474 university students from Slovakia $(\mathrm{M}=22.4, \mathrm{SD}=2.13)$ from which 76.8\% were women, all participating in the Student Life Cohort Study (SLiCE 2016) which mostly focuses on the emigration/migration intentions and risk behaviour of university students. The data for this sample were collected via an online survey. Standard multiple regression was used and the analysis was adjusted for gender.

Findings: Our model explained $26.1 \%$ of the variance in EI. ESE was found to make the largest unique contribution to explaining emigration intentions $(\beta=0.373, p \alpha<0.001)$ followed by $\operatorname{EME~}(\beta=0.138$, $p \alpha<0.05)$ and FME $(\beta=0.121, p \alpha<0.05)$. Therefore, higher emigration self-efficacy, more positive migration experience and more frequent migration experience all have a positive unique effect on EI. Gender was not significant so we couldn't confirm the moderation effect of gender in the relationship between the independent variables and the dependent variable (EI).

Conclusion: We found that emigration self-efficacy, evaluation of migration experience and the frequency of migration experience were related to emigration intentions among young people in Slovakia. These results contribute to a better understanding of the role of these factors in explaining emigration behaviour among young people in Slovakia.
\end{abstract}

Keywords: Emigration intentions, emigration self-efficacy, migration experience, university students.

\section{Introduction}

Migration has been widely studied in recent decades although it has still not been fully explored and understood. The most important reason could be the relatively high complexity of migration: structural factors interact with individual characteristics, social embedding, life course events and psychological characteristics. Migration is also not stable. On the contrary, it is a process over time (Kley, 2009). With the development of information technology, transport and international connections, the world is getting more connected than ever before. This globalization naturally means a rise in migratory behaviour. In Slovakia, there has been an increase in the number of students who aim to move abroad. The Statistical Office of the Slovak Republic indicates that students with secondary education (53.68\%), followed by university students $(21.55 \%)$ are the most numerous group of Slovak emigrants in terms of education (Káčerová, Horváthová, 2014). Bahna (2009) found that young people from Slovakia aged 18-24 had expressed their willingness to leave permanently (36\%) or only for a certain time $(53.3 \%)$. Men generally showed increased willingness to travel abroad. According to the economic activity of the respondents, the overwhelming majority of students (up to 92.9\%) expressed their willingness to leave for work abroad, while $47.4 \%$ of the students expressed their willingness to leave permanently. Also, a more 
frequent and more positive experience with living abroad increased the emigration intentions of students. We can see the importance of studying migration behaviour, especially among the young generation (students) which is confronted with the possibilities of voluntary migration already in high school. According to Kley (2009), completing school as a life-course event is the most important predictor of considering leaving the home city. This could be explained by people's need to plan their future and forthcoming situations and therefore, consider the possibility of leaving the home city.

While examining migration behaviour, it often comes up that actual migration may be experienced differently than originally expected. Changes in migration intentions occur. This could be explained by the fact that pre-migration intentions are not always in accordance with the real course of migration because many obstacles and new opportunities may occur during the migration process. We could perceive migrants as open and self-reliant individuals. The influence of personality characteristics in the process of migration was confirmed by Canache et al. (2013) who found openness to experience as well as extraversion to be positively related to emigration intentions. Gajdošová (2017) found that a higher self-efficacy and a need for change were significant for both genders in predicting emigration plans of Slovak university students. Also, people without migration experience have been found to be less willing to migrate again, compared to those with migration experience (Kupiszewski, 1996).

\section{Objective}

The main objective of this study was to explore whether factors such as emigration self-efficacy, evaluation of migration experience and the frequency of migration experience significantly contribute to the explanation of emigration intentions among young people (under 30 years old) in Slovakia. Based on the theoretical background, we hypothesized that higher emigration self-efficacy, more positive migration experience and more frequent migration experience would all have a positive and unique effect on emigration intentions among university students in Slovakia. We also tested the moderation effect of gender in the relationship between independent variables and dependent variable (emigration intentions).

\section{Research sample and procedure}

The research sample consisted of 474 university students from Slovakia $(\mathrm{M}=22.4, \mathrm{SD}=2.13)$ from which 76.8\% were women, who participated in the Student Life Cohort Study (SLiCE 2016) which focuses on risk behaviour and emigration/migration intentions of university students. The data for this sample were collected via an online survey. For the purposes of our study, standard multiple regression was used and the analysis was adjusted for gender.

\section{Measures}

Emigration intentions and the factors related to emigration intentions in our research sample were measured by the following variables:

- Emigration intentions were measured by a 5-item scale (Chan-Hoong \& Soon, 2011) which required respondents to rate the frequency with which they thought about working or living in another country for the following reasons: (1) overseas education, (2) better job prospects, (3) setting up a business, (4) to work and live in another country for an extended period of time, and (5) emigrating to another country to live there permanently. Each of these five items were scored on a 5-item Likert scale from 1 - never to 5 - all the time. Cronbach's alpha was 0.86 . A higher overall score denotes a greater desire to migrate.

- Emigration self-efficacy was measured by three items: "If I wanted, I could easily leave abroad", "I am convinced that I would manage the process of leaving abroad" and "I am convinced that I would manage my stay abroad." Respondents rated their answers on 5-point Likert type scale, ranged from 1 - completely disagree to 5 - completely agree. A higher overall score indicates higher self-efficacy.

- Emigration experience, perceived as one's previous experience with living abroad, was measured with these two questions:

- The first question was regarding the frequency of living abroad: "How many times have you left your country to live abroad?" rated from 1 - I have never been abroad, 2 - I have never lived abroad, 3 - once, 4 - twice, 5 - three times or more.

- The second question: "How would you now assess your experience with living abroad?" regards the positive, neutral or negative experience with emigration, rated from 1 - very bad, to 5 - very good. 


\section{Results}

The results show certain significant gender differences among young people in Slovakia (<30yr). Males scored higher in self-efficacy and higher in frequency of their migration experience, compared to females. Further details can be found in Table 1.

Table 1. The descriptive characteristics in the measured variables according to gender in our research sample.

\begin{tabular}{|c|c|c|c|c|}
\hline Variable & Men & Women & $\begin{array}{c}\text { Theoretical } \\
\text { range }\end{array}$ & $\begin{array}{c}\text { T-test } \\
\text { value }\end{array}$ \\
\hline $\begin{array}{c}\text { Emigration } \\
\text { intentions }\end{array}$ & $\begin{array}{c}\mathrm{M}=13.52 \\
(\mathrm{SD}=4.92)\end{array}$ & $\begin{array}{c}\mathrm{M}=12.87 \\
(\mathrm{SD}=5.2)\end{array}$ & $5-25$ & -1.16 \\
\hline $\begin{array}{c}\text { Emigration } \\
\text { self-efficacy }\end{array}$ & $\begin{array}{c}\mathbf{M}=\mathbf{1 2 . 4 9} \\
(\mathrm{SD}=\mathbf{2 . 2 4})\end{array}$ & $\begin{array}{c}\mathrm{M}=11.41 \\
(\mathrm{SD}=2.68)\end{array}$ & $3-15$ & $\mathbf{- 3 . 8 3} * * *$ \\
\hline $\begin{array}{c}\text { Evaluation of } \\
\text { migration } \\
\text { experience }\end{array}$ & $\begin{array}{c}\mathrm{M}=3.31 \\
(\mathrm{SD}=2.22)\end{array}$ & $\begin{array}{c}\mathrm{M}=3.39 \\
(\mathrm{SD}=2.28)\end{array}$ & $1-5$ & 0.317 \\
\hline $\begin{array}{c}\text { Frequency of } \\
\text { migration } \\
\text { experience }\end{array}$ & $\begin{array}{c}\mathbf{M}=\mathbf{2 . 1} \\
(\mathrm{SD}=\mathbf{1 . 1 5})\end{array}$ & $\begin{array}{c}\mathrm{M}=1.8 \\
(\mathrm{SD}=1.1)\end{array}$ & $1-5$ & $\mathbf{- 2 . 0 8 2 *}$ \\
\hline
\end{tabular}

Next, our model explained $26.1 \%$ of the variance in emigration intentions. The factor emigration self-efficacy made the largest unique contribution in explaining emigration intentions $(\beta=0.373$, $p \alpha<0.001)$ followed by the factor evaluation of migration experience $(\beta=0.138, p \alpha<0.05)$ and the factor frequency of migration experience $(\beta=0.121, p \alpha<0.05)$. These findings indicate that a higher emigration self-efficacy, more positive migration experience and more frequent migration experience, all have a positive and unique effect on emigration intentions among university students in Slovakia.

Gender was not significant, so we couldn't confirm the moderation effect of gender in the relationship between the independent variables and the dependent variable (emigration intentions). More details are presented in Table 2.

Table 2. The results of linear regression analysis for each independent variable in relation to emigration intentions of young people in Slovakia (adjusted for gender).

\begin{tabular}{|c|c|c|c|}
\hline Variable & $\boldsymbol{\beta}$ & $\mathbf{t}$ & $\mathbf{p}$ \\
\hline $\begin{array}{c}\text { Emigration } \\
\text { self-efficacy }\end{array}$ & 0.373 & 8.53 & $<0.001$ \\
\hline $\begin{array}{c}\text { Evaluation of } \\
\text { migration } \\
\text { Experience }\end{array}$ & 0.138 & 2.48 & 0.014 \\
\hline $\begin{array}{c}\text { Frequency of } \\
\text { migration } \\
\text { Experience }\end{array}$ & 0.121 & 2.22 & 0.027 \\
\hline
\end{tabular}

\section{Discussion}

Many theories of migration point to the economic and demographic factors in attempting to answer what is behind people's intentions to migrate to another country (e.g. Massey et al., 1998). This question arises because migration to another country is often seen as a significant loss of highly talented 
and skilled people, who migrate in search for better career opportunities, better working conditions and a higher salary (Giannoccolo, 2009). Similar research has been conducted in Slovakia and found that job opportunities, the possibility of improving language skills and opportunity to travel and new experiences are the most important reasons for university students who are considering leaving (Benka \& Orosová, 2017). These factors alone, however, do not explain why some people who live in a very similar environmental and socioeconomic conditions, want to migrate to another country whereas others do not.

In order to understand the phenomenon of migration, we examined various psychological factors and their relation to emigration intentions. We confirmed that university students with a higher emigration self-efficacy, more positive migration experience and more frequent migration experience have greater intentions to leave Slovakia. This is in line with Kley (2009) who found that migration experience could be influenced by a bad migration experience, but also by other factors such as the level of income, breaking up with a partner or finding another one. On the other hand, Speare et al. (1975) found that migration experience did not affect considering but only planning migration. It was interpreted as the effect of a migrant's learned skills in dealing with uncertainty and the necessity of making new friends and adapting to their new environment. The main reason could be the fact that people with migration experience are more confident and self-efficient because they have already experienced migration, and therefore, are more prepared and more likely to migrate again. We can agree that migration is an experience full of uncertainty and novelty, mostly because migrants are exploring new locations and cultures, meeting new people and building new relationships. It is important to highlight that this alone is perceived as a positive phenomenon, but only in the case of people's future return as a well-educated workforce. This case certainly applies to Slovakia as like other European countries, Slovakia is also facing globalization and exodus of young and well-educated people to countries with better career opportunities and more developed economies. Therefore, Slovakia, as well as other countries, try to prevent this loss of well-educated students, which could be perceived as a negative phenomenon in the case they choose not to return to their home country.

The biggest limitation of this study concerns the measurement of the factors evaluating migration experience and frequency of migration experience, which we assessed by only single item measures. In the future, it would be helpful to direct our attention to a more complex examination of the relationship between migration experience and emigration intentions and include additional psychological factors important for students' efforts to emigrate. In addition, this study only focused on Slovak university students, so there is potential to study these psychological factors internationally, to provide a deeper understanding of migration behaviour outside of Slovakia. Based on our own research (Hajduch, Orosová, Kulanová, Hal, Lukács, 2018) we have already found that students in Belgium and Slovakia who want to stay in their country of origin (stayers) are more satisfied in life than leavers. Also, the highest percentage of undecided students from the explored countries was found in Belgium (56,5\%). These results could be an indication of another important factors related to emigration intentions not only in Slovakia, but also internationally.

\section{Conclusion}

In this study, we have addressed psychological factors such as emigration self-efficacy, evaluation of migration experience and the frequency of migration experience as important factors related to emigration intentions among university students in Slovakia. We have found that students who want to leave their home country report a higher level of emigration self-efficacy, more positive migration experience and also more frequent migration experience. Although many studies point to mostly economic reasons for migration, they cannot provide the full answer to why some individuals in similar economic conditions choose to stay and some choose to leave their home country. Therefore, we believe that exploring migration from an eclectic perspective may be beneficial for a better understanding of migration behaviour among the young generation of students in Slovakia and outside Slovakia as well.

\section{Acknowledgements}

This work was supported by Research and Development support Agency under the contract No. APVV-0253-11, APVV-15-0662 and Scientific Grant Agency VEGA 1/0713/15. 


\section{References}

Bahna, M. 2009. Pracovná migrácia zo Slovenska po vstupe do EÚ v kontexte krajín EÚ [Labor migration from Slovakia after joining $E U$ in the context of $E U$ countries]. Available at: http://www.sociologia.sav.sk/cms/uploaded/1216_attach_Pracovna_migracia_zo_Slovenska_v_ko ntexte_EU_10.pdf

Benka, J. (2017). Psychological contexts of students' migration from the perspective of the Self-determination theory. In: Orosová, O., Gajdošová, B. (Eds.), Emigration intentions and risk behaviour among university students, p. 147-166

Canache, D., M. Hayes, J. J. Mondak, S. C. Wals. (2013). Openess, extraversion and the intention to emigrate. Journal of Research in Personality 47, 351-355

Chan Hoong, L., \& Soon, D. A. (2011). Study of Emigration Attitudes of Young Singaporeans. Institute of Policy Studies, IPS Working Papers, (19). Retrieved from http://lkyspp.nus.edu.sg/ips/wpcontent/uploads/sites/2/2013/06/wp19_ v2.pdf.

Gajdošová, B. (2017). Intrapersonal and interpersonal factors favouring and hindering plans for long-term migration abroad of university students after finishing university. In: Orosová, O., Gajdošová, B. (Eds.), Emigration intentions and risk behaviour among university students, p. 186-203

Giannoccolo, P, (2009). The Brain Drain: A Survey of the Literature. Università degli Studi di Milano-Bicocca, Department of Statistics, Working Paper No. 2006-03-02. Available at SSRN: https://ssrn.com/abstract=1374329

Hajduch, B., Orosová, O., Kulanová, M., Hal, G. V., Lukács, A. (2018). Life satisfaction and emigration plans of students from four EU countries. European Journal of Public Health, Volume 28, Issue suppl_4, 1 November 2018, cky218.049, available at: https://doi.org/10.1093/eurpub/cky218.049

Káčerová, M., Horváthová, M. (2014). Zahraničná migrácia Slovenska - demografické a priestorové aspekty. Slovak Statistics and Demography, 2, 33-51.

Kley, S. (2009). Explaining migration as a process of cumulative causation in the life course. In: Migremus Arbeitspapiere Nr. 2/2009

Kupiszewski, M. (1996). The future of East-West migration in Europe. In F. W. Carter, P. Jordan, \& V. Rey (Eds.), Central Europe after the fall of the Iron Curtain: Geopolitical perspectives, spatial patterns and trends (pp. 247-268). Frankfurt am Main, Germany: Peter Lang, Europaischer Verlag der Wissenschaften.

Massey, D. S., Arango, J., Hugo, G., Kouaouchi, A., Pellegrino, A., \& Taylor, J. E. (1998). Worlds in motion: Understanding international migration at the end of the millennium. Oxford, England: Clarendon Press.

Speare, A., Goldstein, S. and Frey, W. H. (1975). Residential Mobility, Migration, and Metropolitan Change. Cambridge: Ballinger Publishing. 